\title{
Desain Modifikasi Struktur Jembatan Kalipepe dengan Asymmetric Cable Stayed System dan Prestressed Concrete Segmental Box Girder
}

\author{
Mohammad Akbar Alrasyidi, Tavio, dan Hidayat Soegihardjo Masiran \\ Departemen Teknik Sipil, Fakultas Teknik Sipil dan Perencanaan, Institut Teknologi Sepuluh Nopember (ITS) \\ e-mail: hidayat@ce.its.ac.id
}

\begin{abstract}
Abstrak-Jembatan Kali Pepe merupakan bagian dari proyek jalan bebas hambatan Solo-Kertosono yang melintasi sungai Pepe. Dimana jembatan yang masih dalam tahap pengerjaan ini di desain menggunakan konstruksi PC I girder. Bentang bersih jembatan ini sepanjang 85,2 $\mathrm{m}$ yang dibagi menjadi 2 bagian sama panjang dengan 3 pilar penopang serta memiliki lebar jembatan selebar $12 \mathrm{~m}$. Maka dalam penulisan tugas akhir ini Jembatan Kali Pepe direncanakan ulang sebagai jembatan cable stayed asimetris dengan meggunakan box girder beton prestressed segmental (PC SB girder) dengan bentang $144 \mathrm{~m}$ dan lebar 12,6 m. Susunan kabel pada arah melintang berupa double planes system, sedangkan untuk arah memanjang berupa semi harp pattern. Desain lantai kendaraan berupa pelat beton bertulang dengan gelagar berupa box girder beton prestressed. Pylon (tiang) pada jembatan ini didesain menggunakan material beton bertulang. Permodelan struktur menggunakan fishbone model dengan pembebanan berdasarkan SNI 17252016 dan SNI 28332013. Staging analysis menggunakan metode kantilever dengan backward solution. Hasil yang diperoleh dari perencanaan ini berupa penulangan dan tendon prategang pada gelagar, dimensi kabel, penulangan angker, serta penulangan pylon dalam bentuk laporan dan gambar teknik.
\end{abstract}

Kata Kunci-Asymmetric Cable Stayed, Double Plane System, Jembatan, Prestressed Concrete Segmental Box Girder, Semi Harp Pattern.

\section{PENDAHULUAN}

$\mathbf{J}$ EMBATAN Kali Pepe merupakan bagian dari proyek jalan bebas hambatan Solo-Kertosono yang melintasi sungai Pepe. Dimana jembatan yang masih dalam tahap pengerjaan ini di desain menggunakan konstruksi PC I girder. Bentang bersih jembatan ini sepanjang $85,2 \mathrm{~m}$ yang dibagi menjadi 2 bagian sama panjang dengan 3 pilar penopang serta memiliki lebar jembatan selebar $12 \mathrm{~m}$. Selain itu terdapat konstruksi pile slab, untuk mencegah kelongsoran dari timbunan tinggi, di sisi selatan jembatan sepanjang $50 \mathrm{~m}$ dari abutment. Penggunaan gelagar beton prategang dengan pier di tengah menimbulkan kesan masif dan kokoh, namun kurang memiliki nilai estetika dan dapat mengurangi luas efektif penampang basah pada sungai.

Dalam tugas akhir ini jembatan Kali Pepe direncanakan ulang sebagai jembatan cable stayed asimetris dengan meggunakan box girder beton prestressed segmental (PC SB girder). Modifikasi ini dipilih karena jembatan cable stayed merupakan tipe jembatan bentang panjang dengan tingkat estetika tinggi yang didapat dari susunan pilar, kabel, dan dek jembatan (Yuskar dan Andi, 2005). Namun juga mempertahankan kesan kokoh dari penggunaan prestressed concrete segmental box girder yang memiliki kekakuan torsi yang cukup untuk menahan momen lentur yang besar. Penggunaan tendon prategang sendiri cukup dipasang secara partial karena telah terdapat gaya tekan horisontal pada dek yang ditimbulkan tarikan dari kabel (Leonhardt, 1987). Pemilihan bentuk asimetris sendiri pada modifikasi ini selain mengejar nilai estetika yang lebih tinggi daripada bentuk simetris, juga berdasarkan alasan teoritis berupa pengurangan gaya vertikal pada angkur dengan cara mengurangi kelandaian kabel sehingga sudut optimum kabel yaitu $45^{\circ}$ tercapai (Walther, 1999).

Maka dengan adanya modifikasi ini diharapkan ruang bebas yang lebar untuk luas efektif penampang basah pada sungai dan nilai estetika yang tinggi dapat tercapai. Serta menjadi pemicu bagi kita untuk ke depannya dalam mendesain jembatan cable stayed di Indonesia.

\section{PERKEMBANGAN JEMBATAN}

Pada abad ke-11 sampai dengan 16, jembatan pelengkung masih menjadi desain andalan. Baru kemudian pada tahun 1776 di Inggris untuk kali pertama jembatan besi dibangun, (Jembatan Coalbrookdale yang melintasi Sungai Severn) dengan desain yang berbeda berbentuk setengah lingkaran. Pada abad pertengahan ini jembatan besi yang dibangun pada umumnya masih menggunakan prinsip arc bridge (jembatan berbentuk lengkung)(Ma'arif, 2012). Kemudian pada abad ke-18 masuk pada era baru dalam perencanaan jembatan, yaitu era jembatan gantung. Jembatan jenis ini kali pertama diperkenalkan pada tahun 1825 di Inggris (Jembatan Menai Straits). Pada mulanya penggantung yang digunakan berupa rantai besi, kemudian mengalami perkembangan menjadi baja batangan, dan yang terbaru menggunakan wire steel (kabel baja). Penggunaan kabel baja ini digunakan pada suspension bridge (jembatan kabel suspensi), pertama kali diterapkan pada jembatan Brooklyn, New York, (1883), kemudian diikuti dengan Golden Gate, San Francisco (1937) (Ma'arif, 2012).

Di akhir abad ini banyak diterapkan sistem jembatan baru yang merupakan perkembangan dari suspension bridge yaitu cable stayed bridge (jembatan kabel tetap).Sistem ini menjadi sangat popular dalam desain jembatan karena efektif dan efisien, jembatan ini tergolong jembatan bentang menengah dan panjang, bangunan atas berupa balok elastis yang menerus yang didukung oleh kabel, yang terhubung dengan pylon (tiang). Sistem struktur dari jembatan ini terdiri dari tiga bagian utama yaitu, deck (lantai jembatan), tiang, dan kabel. Kabel merupakan bagian yang paling penting dalam desain jembatan cable stayed, karena berfungsi menyalurkan beban mati dari struktur atas (lantai jembatan) menuju ke pylon (tiang)(Walther, 1999). 


\section{SPESIFIKASI DESAIN}

\section{A. Sistem Kabel}

Sistem jembatan cable stayed berdasarkan penempatan susunan kabelnya memiliki beberapa variasi, baik secara longitudinal maupun secara transversal seperti yang ditunjukkan Gambar 1 dan Gambar 2.
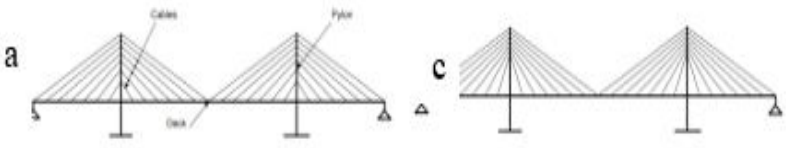

b
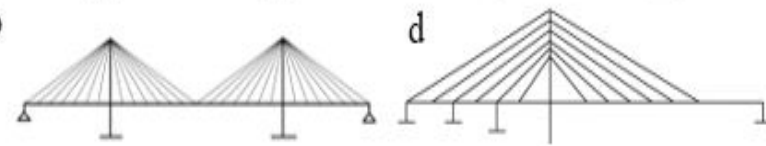

Gambar 1. Tatanan kabel longitudinal (a) Harp pattern, (b) Fan pattern (c) Semi harp pattern, (d) Asymmetric pattern (Walther et al., 1999).
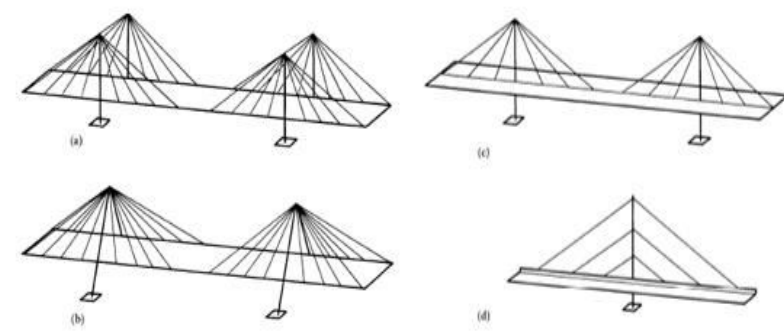

Gambar 2. Tatanan kabel transversal (a) Two vertical plane system, (b) Two inclined plane system, (c) Single plane system, (d) Asymmetric plane system (Troitsky, 1988).

\section{B. Tipe Pylon}

Bentuk pylon dipilih berdasarkan susunan kabel, tinggi muka air, kondisi lingkungan, estetika dan biaya seperti yang ditunjukkan Gambar 3.

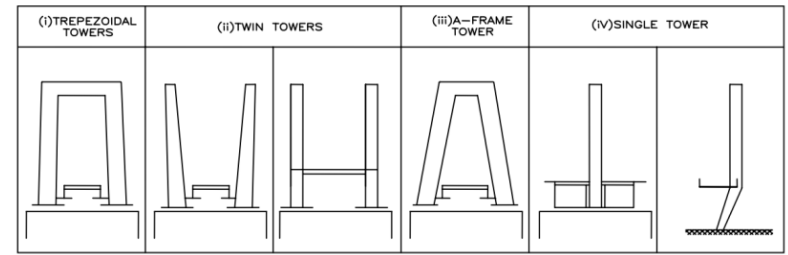

Gambar 3. Tipe pylon jembatan cable-stayed (Troitsky, 1988).

\section{Tipe Gelagar}

Gelagar pada jembatan cable stayed dapat terbuat dari material yang berbeda seperti baja, beton atau komposit baja-beton.seperti yang ditunjukkan Gambar 4 .

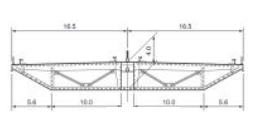

a

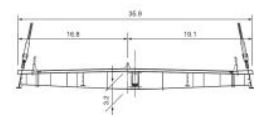

$\mathrm{b}$

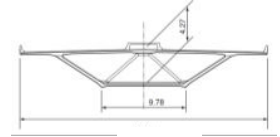

$\mathrm{c}$
Gambar 4. Tipe gelagar (a) Gelagar box baja, (b) Gelagar komposit, (c) Gelagar box beton (ICE Manual of Bridge Engineering, 2008).

\section{Metode Pelaksanaan}

Ada tiga cara yang umum dipakai untuk stiffening girder pada jembatan cable-stayed seperti yang ditunjukkan Gambar 5.

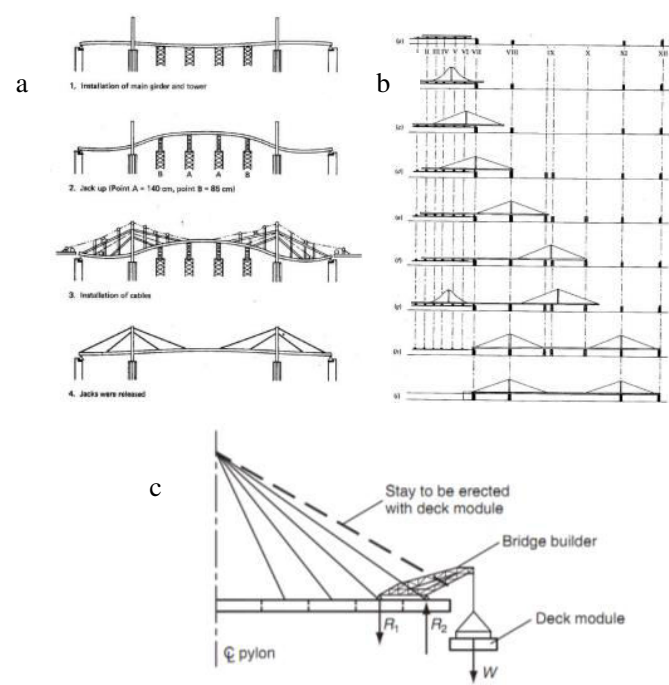

Gambar 5. Metode pelaksanaan (a) Staging method, (b) Push-out method, (c) Cantilever method (Parke and Huson, 2008)

\section{ANALISA DESAIN}

A. Data Perencanaan

- Nama jembatan : Jembatan Kalipepe

- Lokasi : Tol Solo-Kertosono

- Panjang total : $144 \mathrm{~m}$

- Bentang tengah : $121,5 \mathrm{~m}$

- Bentang tepi $\quad: 22,5 \mathrm{~m}$

- Lebar total : $: 12,6 \mathrm{~m}$

- Lebar lajur $\quad: 8,1 \mathrm{~m}(2 / 2 \mathrm{UD})$

- Tipe gelagar : $\quad$ :box beton precast

- Tipe pylon : twin tower cor in situ

- Metode pelaksanaan : cantilever method

\section{B. Data Material}

- Mutu beton -gelagar : $80 \mathrm{MPa}$ -pylon : 50Mpa

- Mutu tulangan $\quad: 400 \mathrm{MPa}$

- Mutu baja tendon : $1486 \mathrm{MPa}(80 \% \mathrm{fpu})$

- Mutu baja kabel : $837 \mathrm{MPa}(45 \% \mathrm{fpu})$

C. Preliminary desain

1. Kabel

Konfigurasi susunan kabel pada arah melintang berupa Double Planes System, sedangkan untuk arah memanjang berupa Semi Harp Pattern. Jarak kabel pada gelagar menurut Whalter dkk. (1999):

- dek beton $(5 \mathrm{~m}-10 \mathrm{~m})$

- dek baja $(15 \mathrm{~m}-25 \mathrm{~m})$

Dipakai jarak kabel pada gelagar $9 \mathrm{~m}$.

\section{Pylon}

Tinggi pylon $(\mathrm{H})$ berbanding dengan bentang jembatan (L), menurut Parke dan Huson (2008) pada jembatan cable stayed simetris dengan kisaran nilai 0,2-0,25.

Namun dalam desain cable stayed asymmetric system, maka panjang bentang yang dipikul 1 pylon menjadi 2 kalinya jembatan cable stayed simetris. Sehingga nilai $\mathrm{H} / \mathrm{L}$ menjadi 0,4-0,5.

$$
\begin{array}{ll}
\text { Direncanakan }(\mathrm{H} / \mathrm{L}) & =0,5 \\
\mathrm{~L} & =121,5 \mathrm{~m} \\
\text { Maka diperoleh } \mathrm{H} & =121,5 \mathrm{~m} \times 0,5
\end{array}
$$


lebih jelasnya lihat Gambar 6 .

$$
=60,75 \mathrm{~m} \approx 60 \text { Untuk }
$$

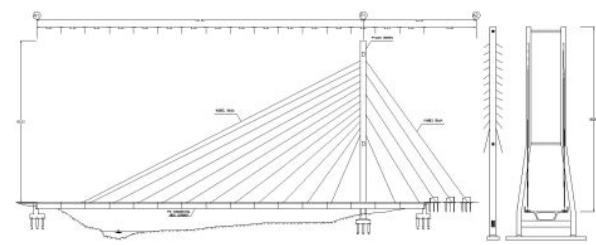

Gambar 6. Tampak memanjang dan melintang jembatan

- Gelagar

Untuk dimensi gelagar mengikuti standar PCI seperti pada Gambar 7.

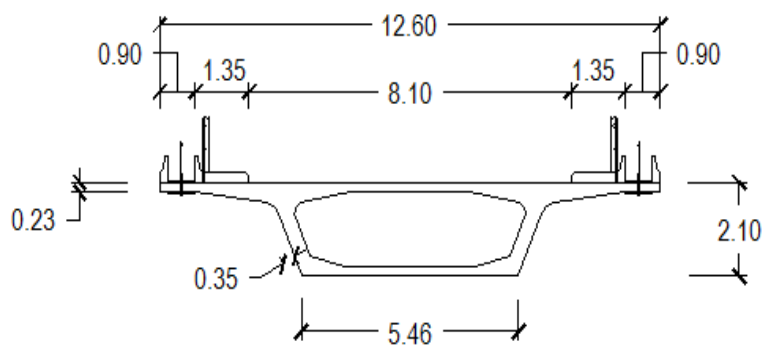

Gambar 7. Dimensi gelagar

\section{Permodelan Fishbone}

Permodelan dilakukan dengan progam bantu MIDAS/Civil dalam model 3D. Dimana elemen kabel dimodelkan sebagai elemen truss yang dihubungkan dengan rigid link support, sedangkan main girder dimodelkan sebagai elemen beam. Untuk lebih jelasnya lihat Gambar 8.

Z

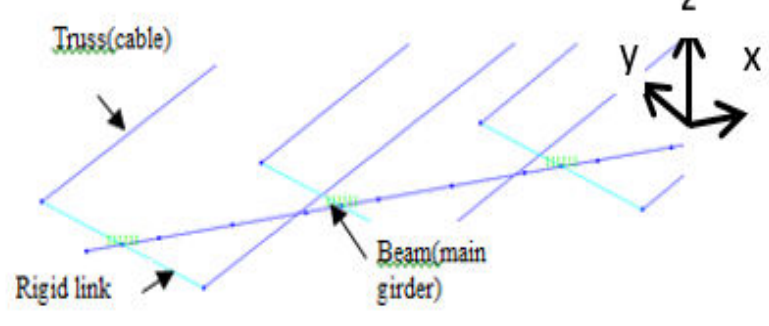

Gambar 8. Permodelan elemen jembatan.

\section{E. Analisa statik}

Beban statik berupa beban mati, beban hidup lalu lintas, beban angin, dan beban suhu. Kombinasi pembebanan statik:

- $1,2 \mathrm{DL}+2 \mathrm{SDL}+1,8 \mathrm{LL}_{\mathrm{i}}+1,8 \mathrm{~TB}_{\mathrm{i}}+1,2 \mathrm{EUn}$

- $1,2 \mathrm{DL}+2 \mathrm{SDL}+1,4 \mathrm{EW}_{\mathrm{S}}+1,2 \mathrm{EUn}$

- $\mathrm{DL}+\mathrm{SDL}+\mathrm{LL}_{\mathrm{i}}+\mathrm{TBi}+0,3 \mathrm{EW}_{\mathrm{S}}+\mathrm{EW}_{\mathrm{Li}}+1,2 \mathrm{Un}$

- $\mathrm{DL}+\mathrm{SDL}+1,3 \mathrm{LL}_{\mathrm{i}}+1,3 \mathrm{~TB}_{\mathrm{i}}+1,2 \mathrm{EUn}$

- $\mathrm{DL}+\mathrm{SDL}+0,7 \mathrm{EW}_{\mathrm{S}}+1,2 \mathrm{EUn}$

Untuk Load Factor masing-masing beban mengacu pada SNI 1725-2016, sedangkan untuk konfigurasi pembebanan $\mathrm{LL}$ dan $\mathrm{EW}_{\mathrm{L}}$ mengacu pada Peraturan Kementerian Pekerjaan Umum Nomor 08/SE/M/2015 tentang "Perencanaan Jembatan Beruji Kabel" yang dapat dilihat pada Tabel 1.
Tabel 1.

Konfigurasi pembebanan LL

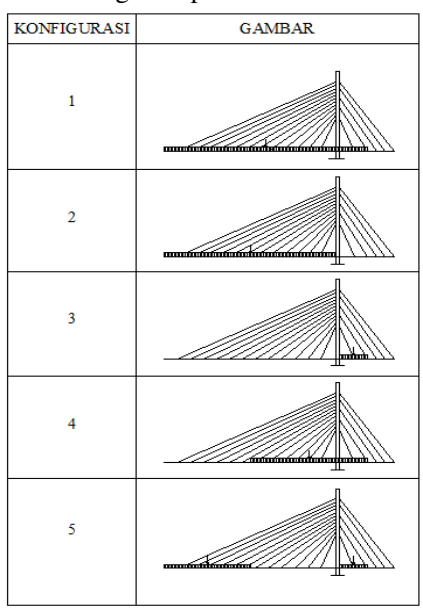

\section{F. Analisa dinamis}

Berupa beban gempa berdasarkan RSNI 2833-2013 dalam peta gempa 1000 tahun dengan kemungkinan terlampaui $7 \%$ dalam 75 tahun dengan metode response spectrum pada progam bantu MIDAS/Civil. Kombinasi pembebanan dinamis :

- $1,2 \mathrm{DL}+2 \mathrm{SDL}+0,5 \mathrm{LL}_{\mathrm{i}}+0,5 \mathrm{~TB}_{\mathrm{i}}+\mathrm{EQ}_{\mathrm{x}}+0,3 \mathrm{EQ}_{\mathrm{y}}$

- $1,2 \mathrm{DL}+2 \mathrm{SDL}+0,5 \mathrm{LL}_{\mathrm{i}}+0,5 \mathrm{~TB}_{\mathrm{i}}+0,3 \mathrm{EQ}_{\mathrm{x}}+\mathrm{EQ}_{\mathrm{y}}$

\section{G. Staging Analysis}

Metode pelaksanaan desain ini menggunakan cantilever method. Urutan pelaksanaan di lapangan sama dengan urutan analisisnya, namun pelaksanaan di lapangan menggunakan forward method sedangkan analisisnya menggunakan backward solution dengan kombinasi berikut.

Tabel 2.

Konfigurasi pembebanan staging

\begin{tabular}{cl}
\hline \hline Kasus & Konfigurasi Beban \\
\hline 1 & DL + Form Traveler \\
\hline \hline
\end{tabular}

\section{H. Struktur Kabel}

Dalam pelaksanaannya, setiap kabel diberi gaya tarik (stressing) terlebih dahulu sebelum dibebani. Dengan menggunakan program bantu MIDAS CIVIL dapat dianalisa besarnya gaya tarik setiap kabel tersebut dengan menggunakan menu unknown load factors calculation.

Tabel 3.

Gaya tarik awal kabel

\begin{tabular}{|l|c|l|l|}
\hline \multicolumn{1}{|c|}{ Kabel } & Pretension & Kabel & Pretension \\
\hline $\mathrm{m} 12$ & $1306 \mathrm{kN}$ & $\mathrm{m} 4$ & $2649 \mathrm{kN}$ \\
\hline $\mathrm{m} 11$ & $2464 \mathrm{kN}$ & $\mathrm{m} 3$ & $2617 \mathrm{kN}$ \\
\hline $\mathrm{m} 10$ & $4497 \mathrm{kN}$ & $\mathrm{m} 2$ & $2440 \mathrm{kN}$ \\
\hline $\mathrm{m} 9$ & $3891 \mathrm{kN}$ & $\mathrm{m} 1$ & $1688 \mathrm{kN}$ \\
\hline $\mathrm{m} 8$ & $3039 \mathrm{kN}$ & $\mathrm{s}$ & $3071 \mathrm{kN}$ \\
\hline $\mathrm{m} 7$ & $2393 \mathrm{kN}$ & $\mathrm{s}$ & $5630 \mathrm{kN}$ \\
\hline $\mathrm{m} 6$ & $2133 \mathrm{kN}$ & $\mathrm{s}$ & $4981 \mathrm{kN}$ \\
\hline $\mathrm{m} 5$ & $2279 \mathrm{kN}$ & $\mathrm{s}$ & $6003 \mathrm{kN}$ \\
\hline
\end{tabular}

Kemudian dari gaya-gaya maksimum akibat pemebebanan dapat diperoleh kebutuhan strand dan luas penampang kabel yang sebenarnya. Untuk lebih jelasnya dapat dilihat pada Tabel 4 
Tabel 4.

Jumlah strand kabel perlu

\begin{tabular}{|c|c|c|c|c|c|c|c|c|}
\hline Kabel & $\begin{array}{c}\mathrm{f} i \mathrm{ijin} \\
\text { (MPa) }\end{array}$ & $\begin{array}{c}\mathrm{P} \\
(\mathrm{kN})\end{array}$ & $\begin{array}{c}\text { Asc pre } \\
\left(\mathrm{mm}^{2}\right)\end{array}$ & $\begin{array}{c}\mathrm{N} \text { pre } \\
\text { (kabel) }\end{array}$ & $\begin{array}{l}\text { A perlu } \\
\left(\mathrm{mm}^{2}\right)\end{array}$ & $\begin{array}{l}\mathrm{N} \text { perlu } \\
\text { (kabel) }\end{array}$ & $\begin{array}{l}\text { N pakai } \\
\text { (kabel) }\end{array}$ & $\begin{array}{c}\text { A aktual } \\
\left(\mathrm{mm}^{2}\right)\end{array}$ \\
\hline m12 & 837 & 6178 & 1680 & 12 & 7381 & $\begin{array}{r}52.7 \\
\end{array}$ & 61 & 8540 \\
\hline $\mathrm{m} 11$ & 837 & 8629 & 3080 & 22 & 10309 & 73.6 & 85 & 11900 \\
\hline $\mathrm{m} 10$ & 837 & 11571 & 6020 & 43 & 13824 & $\begin{array}{ll}98.7 \\
\end{array}$ & 127 & 17780 \\
\hline m9 & 837 & 9617 & 5180 & 37 & 11490 & 82.1 & 91 & 12740 \\
\hline $\mathrm{m} 8$ & 837 & 7785 & 4340 & 31 & 9302 & $\begin{array}{ll}66.4 \\
\end{array}$ & 73 & 10220 \\
\hline $\mathrm{m} 7$ & 837 & 6673 & 3080 & 22 & 7973 & 56.9 & 61 & 8540 \\
\hline $\mathrm{m} 6$ & 837 & 6351 & 2660 & 19 & 7587 & 54.2 & 61 & 8540 \\
\hline $\mathrm{m} 5$ & 837 & 6646 & 3080 & 22 & 7941 & 56.7 & 73 & 10220 \\
\hline $\mathrm{m} 4$ & 837 & 7132 & 4340 & 31 & 8521 & 60.9 & 73 & 10220 \\
\hline $\mathrm{m} 3$ & 837 & 6880 & 4340 & 31 & 8220 & 58.7 & 61 & 8540 \\
\hline $\mathrm{m} 2$ & 837 & 6306 & 3080 & 22 & 7534 & 53.8 & 55 & 7700 \\
\hline $\mathrm{m} 1$ & 837 & 5371 & 2660 & 19 & 6417 & 45.8 & 61 & 8540 \\
\hline s1 & 837 & 3921 & 4340 & 31 & 4685 & 33.5 & 55 & 7700 \\
\hline s2 & 837 & 8460 & 7700 & 55 & $\begin{array}{l}10107 \\
\end{array}$ & 72.2 & 127 & 17780 \\
\hline s3 & 837 & 7262 & 6020 & 43 & 8676 & 62.0 & 127 & 17780 \\
\hline 54 & 837 & 8798 & 7700 & 55 & 10511 & 75.1 & 127 & 17780 \\
\hline 55 & 837 & 10135 & 8540 & 61 & 12108 & 86.5 & 127 & 17780 \\
\hline
\end{tabular}

\section{Struktur Gelagar}

1.Tegangan ijin bahan beton

Berikut adalah tegangan ijin beton prategang berdasarkan SNI T-12-2004 Pasal 4.4.1.2.

Kuat tekan beton yang direncanakan pada umur saat dilakukan transfer $\left(f_{c i}{ }^{\prime}\right)$, dinyatakan dalam satuan $\mathrm{MPa}$.

$$
\begin{aligned}
f_{c i}{ }^{\prime} & =0,7 f c \\
& =0,7.80 \mathrm{MPa} \\
& =56 \mathrm{MPa}
\end{aligned}
$$

A. Tegangan ijin beton saat transfer

- $\sigma_{\text {tekan }}=0,6 f_{c i}{ }^{\prime}$

$$
=0,6.56
$$$$
=34 \mathrm{MPa}
$$

- $\sigma_{\text {tarik }}=0,25 \sqrt{f_{c i}}$

$$
=0,25 \cdot \sqrt{56}
$$

$=1,87 \mathrm{MPa}$ (namun diusahakan tidak ada tarik untuk segmental)

B. Tegangan ijin beton saat servis

- $\sigma_{\text {tekan }}=0,45 f_{c}$,

$=0,45.80$

$=36 \mathrm{MPa}$

- $\sigma_{\text {tarik }}=0,5 \sqrt{f_{c}^{\prime}}$

$=0,5 \cdot \sqrt{80}$

$=4,47 \mathrm{MPa}$ (namun diusahakan tidak ada tarik untuk segmental)

2. Kehilangan Prategang

- Akibat perpendekan elastis beton

$$
\begin{gathered}
E S=K_{E S} \cdot \frac{E_{S}}{E_{c i}} \cdot f_{c i r} \\
\% \text { Loss }=1,74 \%
\end{gathered}
$$

- Akibat gesekan kabel

$$
\begin{gathered}
\frac{F 2-F 1}{F 1}=-K . L-\mu . \alpha \\
\% \text { Loss }=1,8 \%
\end{gathered}
$$

- Akibat slip angkur

$$
\begin{gathered}
A N C=\Delta_{f s}=\frac{\Delta_{\alpha} \cdot E_{s}}{L} \\
\% \text { Loss }=2,79 \%
\end{gathered}
$$

- Akibat rangkak beton

$$
C R=K_{c r} \cdot \frac{E_{S}}{E_{c}} \cdot\left(f_{c i r}-f_{c d s}\right)
$$

$\%$ Loss $=2,58 \%$

- Akibat susut beton

$$
\begin{gathered}
S H=8,2 \cdot 10^{-6} \cdot K_{S h} \cdot E_{S} \cdot\left(1-0,06 \cdot \frac{V}{S}\right) \cdot(100-R H) \\
\% \text { Loss }=1,59 \%
\end{gathered}
$$

- Akibat relaksasi baja

$$
\begin{gathered}
R E=\left(K_{r e}-J(S H+C R+E S)\right) \times C \\
\% \text { Loss }=2,2 \%
\end{gathered}
$$

3. Kontrol Diagram Tegangan

Tahap kantilever

Contoh perhitungan As CL menggunakan tendon 6-27 pada flens atas,

Serat atas

$$
\mathrm{F}=-\frac{\mathrm{F}}{\mathrm{A}}-\frac{\text { F.e.y }}{\mathrm{I}}+\frac{\mathrm{M} \cdot \mathrm{y}}{\mathrm{I}}=-11,7 \mathrm{MPa}>-34 \mathrm{MPa}
$$

Serat bawah

$$
\mathrm{F}=-\frac{\mathrm{F}}{\mathrm{A}}+\frac{\text { F.e.y }}{\mathrm{I}}-\frac{\text { M.y }}{\mathrm{I}}=-3,06 \mathrm{MPa}<0 \mathrm{MPa}
$$

Tahap servis

Contoh perhitungan As CL menggunakan tendon 6-27 pada flens atas dan tendon 6-55 pada flens bawah,

Serat atas

$$
\begin{aligned}
F & =-\frac{F a+F b}{A}+\frac{F b \cdot e \cdot y}{I}-\frac{F a . e . y}{I}-\frac{M . y}{I} \\
& =-10,3 \mathrm{MPa}<0 \mathrm{MPa}
\end{aligned}
$$

Serat bawah

$$
\begin{aligned}
F & =-\frac{F a+F b}{A}-\frac{\text { Fb.e.y }}{I}+\frac{\text { Fa.e.y }}{I}+\frac{\text { M.y }}{I} \\
& =-21,7 \mathrm{MPa}>-36 \mathrm{MPa}
\end{aligned}
$$

\section{Analisa 1 kabel putus}

Disimulasikan kabel terluar putus seperti terlihat pada Gambar 9 dan dikontol kembali tegangan yang terjadi.

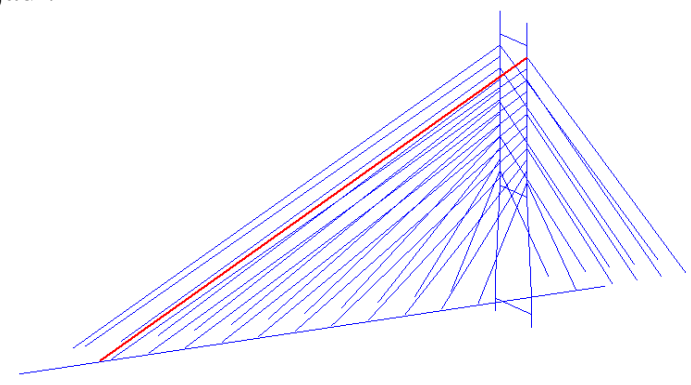

Gambar 9. Posisi kabel putus 1.

Contoh perhitungan pada As CL

Serat atas

$$
\begin{aligned}
F & =-\frac{F a+F b}{A}+\frac{F b . e . y}{I}-\frac{\text { Fa.e.y }}{I}-\frac{\text { M.y }}{I} \\
& =-10,5 \mathrm{MPa}<0 \mathrm{MPa}
\end{aligned}
$$

Serat bawah

$$
\begin{aligned}
\mathrm{F} & =-\frac{\mathrm{Fa}+\mathrm{Fb}}{\mathrm{A}}-\frac{\text { Fb.e.y }}{\mathrm{I}}+\frac{\text { Fa.e.y }}{\mathrm{I}}+\frac{\text { M.y }}{\mathrm{I}} \\
& =-21,4 \mathrm{MPa}>-36 \mathrm{MPa}
\end{aligned}
$$

\section{Kontrol Momen Retak}

Contoh perhitungan pada As CL

Syarat, $\mathrm{Mu}<\mathrm{M}_{\mathrm{cr}}=\mathrm{F}\left(\mathrm{e}+\frac{\mathrm{r}^{2}}{\mathrm{y}}\right)+\frac{\mathrm{f}_{\mathrm{r}} \cdot \mathrm{I}}{\mathrm{y}}$

$8431 \mathrm{kNm}<75550 \mathrm{kNm}$...memenuhi

\section{Kontrol Momen Batas}

Contoh perhitungan pada As CL

Menghitung tinggi tegangan beton 


$$
\begin{gathered}
\mathrm{a}=\frac{\mathrm{T}}{0,85 \cdot \mathrm{fc}^{\prime} \cdot \mathrm{bw}} \\
\text { Syarat, } \mathrm{Mu}<\emptyset \mathrm{Mn}=0,9\left(\mathrm{~T}\left(\mathrm{~d}-\frac{\mathrm{a}}{2}\right)\right) \\
8431 \mathrm{kNm}<94793 \mathrm{kNm} . . . \text { memenuhi }
\end{gathered}
$$

\section{Kontrol Lendutan}

Lendutan ke bawah akibat beban servis $\Delta 1=0,49 \mathrm{~m}$ (output midas)

Lendutan ke atas akibat prategang

$\Delta 2=\frac{\text { 5.F.e. } \mathrm{L}^{2}}{48 . \mathrm{E} . \mathrm{I}}-\frac{\mathrm{M} \cdot \mathrm{L}^{2}}{8 . \mathrm{E} . \mathrm{I}}=0,47 \mathrm{~m}$

Lendutan total

Berdasarkan SNI T-12-2004 Ps. 9.2.1

Syarat, $\Delta=\Delta 1-\Delta 2 \leq \Delta \mathrm{ijin}$

$$
\begin{aligned}
& =0,49-0,47 \leq \mathrm{L} / 800 \\
& =0,02 \mathrm{~m} \leq 144 / 800 \\
& =0,02 \mathrm{~m}<0,18 \mathrm{~m} . . . \text { memenuhi }
\end{aligned}
$$

8. Kontrol Torsi

$$
\begin{aligned}
& \text { Kuat torsi penampang } \\
& \begin{aligned}
\text { Tc } & =6 \sqrt{f c^{\prime}} \cdot \sqrt{1+\frac{10 \cdot \frac{F}{A}}{f c^{\prime}}} \cdot \sum \eta 1 \cdot \mathrm{x} 1^{2} \cdot \mathrm{y} 1 \\
& =3,85 \cdot 10^{4} \mathrm{kNm}
\end{aligned}
\end{aligned}
$$

Syarat torsi ijin,

$\frac{T u}{\emptyset T c}<0,25$

$\frac{3689,5}{0,7.38500}<0,25$

$0,14<0,25$ (memenuhi)

Maka tidak diperlukan tulangan puntir

\section{Penulangan box}

- Penulangan lentur

Untuk mengantisipasi momen terutama arah transversal akibat kendaraan, maka dipasang tulangan lentur arah transversal dimana permodelannya menggunakan progam bantu SAP2000 seperti terlihat pada Gambar 10.

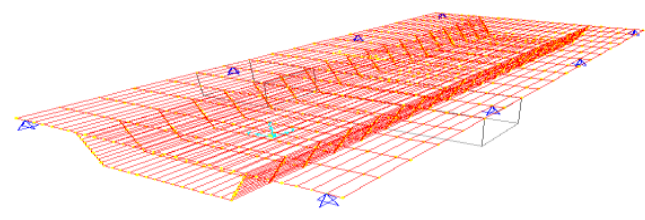

Gambar 10. Permodelan elemen box.

Maka dipasang tulangan D22-50 pada flens atas dan bawah serta D22-70 pada web

- Penulangan web

Direncanakan tulangan geser dipasang pada daerah web

Kuat geser beton

1. Kondisi retak geser terlentur

$$
\begin{aligned}
\mathrm{V}_{\mathrm{ci}} & =\frac{\sqrt{f c l}}{20} b w \cdot d+V d+\frac{V i \cdot M c r}{M \max } \\
& =14448 \mathrm{kNm}
\end{aligned}
$$

2. Kondisi retak geser badan

$$
\mathrm{V}_{\mathrm{cw}}=0,3\left(\sqrt{f c^{\prime}}+f p e\right) b w \cdot d+V p
$$

$$
\begin{aligned}
& \quad=6210 \mathrm{kNm} \ldots \text { menentukan } \\
& \mathrm{Vu}=15893 \mathrm{kN} \\
& \mathrm{Vs}=\mathrm{Vu} / \phi-\mathrm{Vc} \\
& \quad=15893 / 0,75-6210=14981 \mathrm{kN}
\end{aligned}
$$

Digunakan sengkang 4 kaki

$\mathrm{S}_{\text {perlu }}=\frac{4.0,25 \pi \cdot 25^{2} \cdot 400 \cdot 2223}{14981 \cdot 10^{3}}=116 \mathrm{~mm}$

Maka dipasang sengkang D25-100

10. Perencanaan shear-key joint

Direncanakan dimensi shear-key joint tiap segmen seperti Gambar 11.

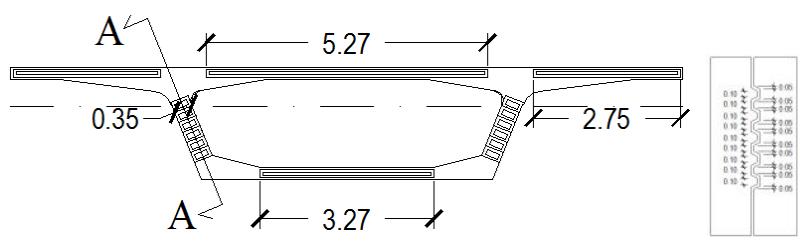

POT A-A

Gambar 11. Desain shear-key joint.

kuat geser beton

1. Kondisi retak geser terlentur

$$
\begin{aligned}
\mathrm{V}_{\mathrm{ci}} & =\frac{\sqrt{f c l}}{20} b w . d+V d+\frac{V i \cdot M c r}{M \max } \\
& =21219 \mathrm{kNm} \text {...menentukan }
\end{aligned}
$$

2. Kondisi retak geser badan

$$
\begin{aligned}
& \mathrm{V}_{\mathrm{cw}}=0,3\left(\sqrt{f c^{\prime}}+f p e\right) b w \cdot d+V p \\
& \quad=140841 \mathrm{kNm} \\
& \mathrm{Vu}=15893 \mathrm{kN} \\
& \mathrm{Vs}=\mathrm{Vu} / \phi-\mathrm{Vc} \\
& =15893 / 0,75-21219=-28 \mathrm{kN}
\end{aligned}
$$

Maka tidak diperlukan tulangan geser tambahan

\section{J. Desain perletakan dan expansion joint}

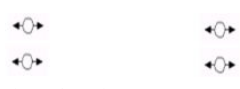

Gambar 12. Asumsi perletakan jembatan.

keterangan: bergerak ke arah longitudinal.

Dari hasil analisa diperoleh

$$
\begin{aligned}
& \mathrm{H}=2400 \mathrm{kN} \\
& \mathrm{V}=12500 \mathrm{kN}
\end{aligned}
$$

Digunakan unidirectional pot bearing VSL tipe PU 1800/1300/H2 EN dengan Vmax 18135 kN dan Hmax $3900 \mathrm{kN}$.

Sedangkan untuk mengantisipasi deformasi pada ujung gelagar yang sebesar $63 \mathrm{~mm}$, digunakan expansion joint tipe DS160 dengan toleransi perpindahan sebesar $160 \mathrm{~mm}$.

\section{K. Struktur Pylon}

Kolom pylon

Luas penampang $=5 \mathrm{~m}^{2}$

Dari hasil analisa didapat :

132 buah D36 (2,69\%) dengan As $=134376 \mathrm{~mm}^{2}$ dan sengkang 4 D25-75 


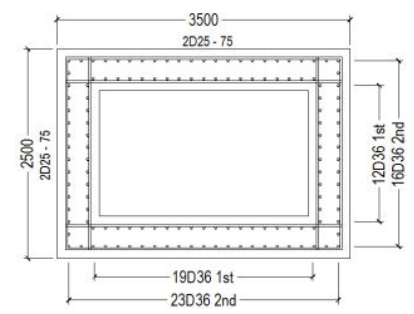

Gambar 13. Desain penulangan kolom.

\section{Lower cross beam}

Luas penampang $=3 \mathrm{~m}^{2}$

Dari hasil analisa didapat :

$60 \mathrm{D} 25(1,10 \%) \mathrm{As}=32885 \mathrm{~mm}^{2}$

dan sengkang 4 D22-200

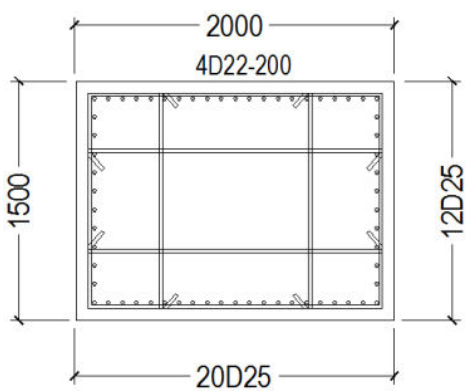

Gambar 14. Desain penulangan lower cross beam

Top cross beam

Luas penampang $=2,25 \mathrm{~m}^{2}$

Dari hasil analisa didapat :

$56 \mathrm{D} 40(1,10 \%)$ As $=70371 \mathrm{~mm}^{2}$

dan sengkang 4 D22-200

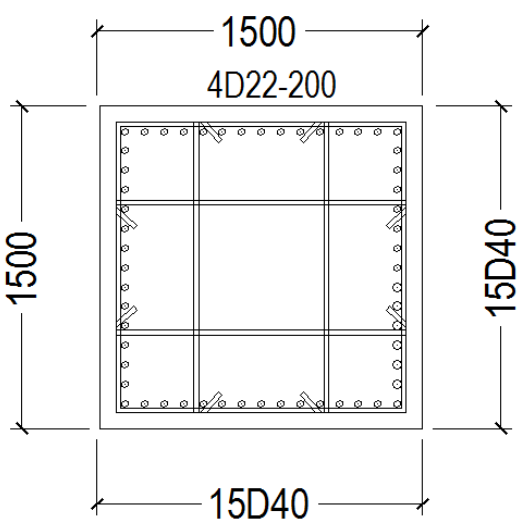

Gambar 15. Desain penulangan lower cross beam

\section{Kontrol Stabilitas Aerodinamis}

1. Klasifikasi efek psikologis baik berdasarkan amplitudo maupun percepatan getaran masuk dalam kategori dapat diterima (acceptable)

2. Efek flutter menghasilkan $\mathrm{V}_{\text {kritis actual }}$ sebesar 69,78 $\mathrm{m} / \mathrm{dt}>\mathrm{V}_{\text {rencana }}$ sebesar $29,3 \mathrm{~m} / \mathrm{dt}$, sehingga tidak terjadi ayunan/flutter
3. Perbandingan frekuensi lentur dan torsi mencapai 2,32 sehingga periode puncak terjadi lentur tidak bersamaan dengan periode puncak terjadi torsi. Untuk lebih jelasnya lihat Gambar 16.

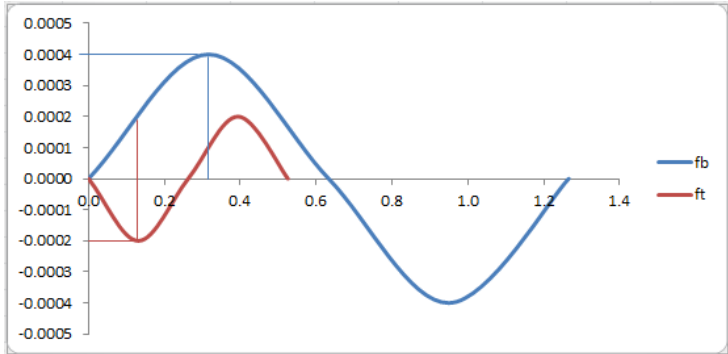

Gambar 16. Grafik efek flutter $T_{\text {bending }}=1,26$ dan $T_{\text {torsion }}=0,53$

\section{PENUTUP}

Berdasarkan analisa yang telah dilakukan dapat disimpulkan beberapa hal, yaitu:

1. Digunakan kabel penggantung tipe ASTM A 416-05 Grade 270 dengan jumlah strand bervariasi antara 55127 strand.

2. Digunakan tendon prategang 6-27 untuk flens atas dan 6-55 untuk flens bawah.

3. Digunakan tulangan lentur pada flens D22-50, D22-70 pada web dan sengkang D25-100.

4. Digunakan tulangan 132D36 dan sengkang 4D25-75 pada kolom pylon, tulangan 60D25 dan sengkang 4D22200 pada lower cross beam, serta tulangan 56D40 dan sengkang 4D22-200 pada top cross beam.

5. Berdasarkan analisa stabilitas aerodinamis dan analisa 1 kabel putus, jembatan dalam kondisi aman.

\section{DAFTAR PUSTAKA}

[1] AASHTO-PCI-ASBI Standard Segment For Span-By-Span Construction, 2011.

[2] Gimsing, N.J. 1983. Cable Supported Bridges, Concepts and Design, John Wiley and Sons, New York.

[3] Leonhardt, F., 1987. Cable Stayed Bridges With Prestressed Concrete. Journal of the Prestressed Concrete Institute, September-Oktober.

[4] Ma'arif, Faqih. 2012. "Analisa Struktur Jembatan”. Universitas Negeri Yogyakarta (Juli).

[5] Ned, T. L. \& Burn, H., 1993. Desain Struktur Beton Prategang. Third ed. Jakarta: Erlangga.

[6] Parke, Gerard, dan Nigel Hewson. 2008. ICE Manual of Bridge Engineering Second Edition. London, Thomas Telford Ltd.

[7] Soegiharjo, H, Irawan D, Harwijono. 2007. Kuliah Rekayasa Jembatan Bentang Panjang. Jurusan Teknik Sipil ITS

[8] Troitsky, M.S. .1988. Cable-stayed Bridge Theory and Design. London, BSp Professional Books.

[9] Walter, R. , Houriet, Isler, Moia, Klein. 1999. Cable Stayed Bridge Second Edition. London, Thomas Telford Publising.

[10] Yuskar dan Andi, 2005. Kajian Sambungan Antara Pilar dan Kabel Pada Jembatan Cable Stayed, Jakarta: Universitas Indonesia. 